\title{
Teachers' Attitudes towards Behaviour Patterns in Social Conflicts in Primorsko-Goranska County in Croatia
}

NATAŠA VlaH ${ }^{\star 1}$, LUCIJA JANČEC ${ }^{2}$, AND RenATA ČEPIĆ ${ }^{3}$

$\approx$ The aim of the empirical research is to determine primary school teachers' attitudes towards behaviour patterns in social conflict. A primary school teacher is the role model for his/her pupils, so in the context of the theory of hidden curriculum, the purpose of the study is determining a better understanding of teacher's needs for further conflict resolution training. A Scale of Attitudes toward social conflicts was applied to a stratified sample of 155 teachers in the Primorje-Gorski Kotar County, Croatia, measuring three patterns of behaviour: avoidance/adaptation, cooperation, and winning. According to the results, the teachers most frequently have positive attitudes toward a pattern of cooperation, and most seldom toward a pattern of winning. Winning is negatively correlated with cooperation, and positively correlated with avoidance/adaptation. The authors recommended systematic social skills training necessary for managing conflict for a specific group of teachers. The authors believe these findings could raise interest and awareness for further studies in the field of conflict studies in education.

Keywords: avoidance, cooperation, conflict resolution training, teachers, winning

$1 \quad{ }^{*}$ Corresponding Author. Faculty of Teacher Education, University of Rijeka, Croatia; natasa.vlah@gmail.com

2 "Our Children Society" at Opatija, Croatia

3 Faculty of Teacher Education, University of Rijeka, Croatia 


\section{Stališča učiteljev do vzorcev obnašanja v socialnih konfliktih v Primorsko-Goranski regiji na Hrvaškem}

Nataša Vlah* ${ }^{\star}$ Lucija JanČEC In Renata Čepić

$\propto$ Cilj empirične raziskave je ugotoviti stališča osnovnošolskih učiteljev do vzorcev obnašanja v socialnih konfliktih. Osnovnošolski učitelj je vzornik svojim učencem; tako je v kontekstu teorije skritega kurikuluma namen raziskave bolje razumeti učiteljeve potrebe za nadaljnja usposabljanja na področju razreševanja konfliktov. V raziskavi je sodelovalo 155 učiteljev iz regije Primorje - Gorski Kotar na Hrvaškem. Uporabljena je bila lestvica stališč do socialnih konfliktov, s katero so merili tri vzorce obnašanja: izogibanje/prilagajanje, sodelovanje in zmagovalno obnašanje. Glede na rezultate imajo učitelji najpogosteje pozitivno stališče do vzorca sodelovanja in najredkeje do vzorca zmagovalnosti. Ta je negativno povezana s sodelovanjem in pozitivno $\mathrm{z}$ izogibanjem/s prilagajanjem. Avtorji prispevka predlagajo načrtno usposabljanje za pridobivanje socialnih veščin, nujno potrebnih za obvladovanje konflikta za izbrane skupine učiteljev. Menijo, da bodo izsledki spodbudili zanimanje za nadaljnje raziskave na področju preučevanja konfliktov v izobraževanju.

Ključne besede: izogibanje, sodelovanje, usposabljanje za razreševanje konfliktov, učitelji, zmagovanja 


\section{Introduction}

Many authors support the idea that teachers, through their behaviour in school, implicitly mediate their values and attitudes to their pupils (Gordon, 1982; McDiarmid, 1987; Verhoeve, 2008; Hodkinson, 2005; Weldon, 2010; Zembylas, 2011). By observing their teachers/models, pupils can learn new forms of behaviour, solidify pre-existing ones and (de)motivate themselves to perform (un)desirable behaviours. Accordingly, the fundamental question of our research paper is to obtain insight into the attitudes of primary school teachers towards behaviour patterns in situations of social conflict.

Experience, through which pupils learn the sum of conditionally parallel interaction processes that occur as part of interpersonal relations and everyday life with their teacher, through teacher's verbal and non-verbal behaviour, has a significant impact on shaping pupils' behaviour and character. Therefore, the relationship between pedagogical intention and pedagogical result (in curriculum terminology: educational output), can be understood only by accepting this invisible reality, the hidden curriculum (Bloom, 1972; Seddon, 1983; Cindric et al., 2010; Miljak, 2007; Bašić, 2000; Jančec, Tatalović Vorkapić, \& Lepičnik Vodopivec, 2014). What is learnt through the hidden curriculum remains in memory for a longer time as it is pervasive and present throughout the entirety of one's education. Thus, the lessons of the hidden curriculum are part of daily experiences that become embedded (Husen \& Postlethwaite, 1994, as cited in Dolar Bahovec, \& Bregar Golobič, 2004).

The teacher's values and views do not always have to be clearly expressed in the tasks teacher sets, or in the formal curriculum, but can be also reflected in the teaching style, the manner in which a class is organised and in various other factors that influence the pupil's behaviour. However, in this paper, we are interested in one specific segment of the teacher's value system, the one that is most likely expressed through the hidden curriculum: teacher's attitudes toward behaviour in conflict resolution.

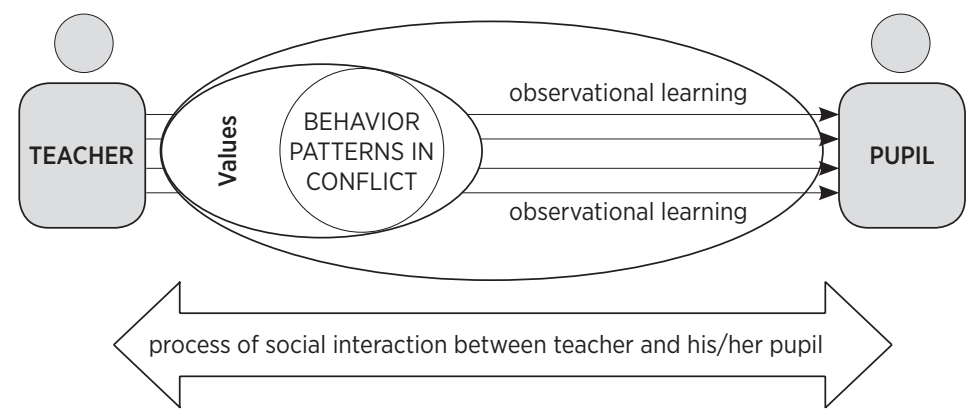

Figure 1. The theoretical model of teacher behaviour patterns in social conflicts 
The structural definition of attitude states that an attitude is formed by an individual's beliefs and values and thus influences the intention behind a certain form of behaviour in a specific situation (Pennington, 1997). We understand these attitudes, as possible effects on pupils. Pupils learn from their social environment and are socialized through observational learning (Bandura, $1978,1986)$, as a part of the hidden curriculum. Figure 1 gives a visual depiction of this theoretical model, with the one-way arrows representing observational learning, and the two-way arrow representing the process of social interaction between the teacher and his/her pupil. The purpose of the model is to clarify our theoretical understanding of teacher's attitudes towards behaviour patterns in social conflicts in the school and pre-school environments.

A social conflict is a legal form of exhibiting differences and normal elements of communication processes while also offering a possibility for personal and social improvement and representing an area of systematic scholarly research and effective management (Vlah, 2010). Therefore, conflict as a contradiction to our current values, expectations, and goals, whatever these might be, has to be dealt with in the context changes in attitudes and behaviours applied to the interactions between school teachers and pupils, colleagues, parents, and others. According to conflict resolution theory (Thomas \& Kilman, 1977; Wilmot \& Hocker, 1998; Weeks, 200o), social conflicts can be beneficial and useful if and when the participants of social conflicts have been quality prepared for constructive behaviour regarding their attitudes and communication skills (Galtung, 2000).

Conflict resolution theory (Weeks, 2000) is based on the values of the Western civilizational and cultural circle (Altras \& Penda, 2005), which upholds values, such as respecting human and civil rights, preserving a healthy environment, creating a new order of freedom, safety and security, respecting cultural diversity, establishing cooperation in all areas among equal nations, freely expressing thought and creating all the necessary preconditions for the elimination of all forms of discrimination (based on gender, ethnic, confessional, social and other grounds).

With respect to conflict resolution theory, there are interesting findings of Basit et al. (2010), which point that certain attitudes and qualities are basic to successful conflict prevention and resolution.

Teachers have to treat their students properly and respect them as individuals. They need to be affectionate, leading as a role model and concerned for welfare of students. This concern is represented in tone of voice, facial expressions, and other everyday behavior. It will create an effective learning environment, prevent classroom conflicts and will help in coping with them effectively (Basit et al., 2010, p. 217). 
Within this context, conflict resolution patterns are understood as theoretical constructs used to describe the most commonly applied behaviours in conflicts. Those behaviours are habits that those who perform them are not even always aware of. Behaviour patterns in conflict cited by Weeks (2000) differ according to levels of desirability or common utility and quality of future relationships as shown in Figure 2.

\begin{tabular}{ll}
\hline Level of common utility and quality of future relationships & Conflict resolution patterns \\
\hline The highest level & Cooperation \\
Middle level & Accommodation, compromise \\
The Lowest level & Winning and avoiding \\
\hline
\end{tabular}

Figure 2. Conflict resolution patterns according to level of common utility and quality of future relationships (Weeks, 2000, according to Vlah, 2013, p. 34)

Every upper level is more functionally valuable for the quality of conflict management. Each upper level provides a more constructive long-term relationship between participants in the conflict. The cooperation pattern is at the highest level, which is reached when both sides in a conflict find a solution that meets some of their individual and common needs. The lowest level is reached when one side is defeated, in other words, when one side wins and the other loses and or when relations between two conflicted sides are terminated to mutual loss. Winning and avoiding belong to this level (Weeks, 2000). The behaviour above patterns are used in everyday life, and they affect the quality of interpersonal relations in different ways, thus also affecting the teachers who participate in pupils' lives every day.

According to Morris-Rothspupil and Brassard (2006), constructive conflict management strategies are important in maintaining a positive environment in the classroom; therefore, the teachers that scored low on avoidance were predicted to endorse the use of positive classroom management strategies (e.g., integrating, compromising) more than those that scored high on avoidance. However, the avoidant pattern was found to be the most frequent communication model between the teachers themselves (Fields, 1998), while the same author also discovered that teachers are of the opinion that collaboration is only necessary for situations of teacher-parent conflict. Frymier and Houser (2000) asked students about which communications skills they thought a teacher must possess in order to teach effectively. Students responded that they considered referential skills, ego support, and conflict management to be the most important for quality teaching. Therefore, Cornile, Pestle and Vanvy (1999) in their research with 
156 elementary school teachers in the US, using Rahim Organizational Conflict Inventory II, determined that teachers' conflict management styles were different in all five styles of conflict management from those of a normative group of the business managers. No differences were found between responses of teachers in urban and nonurban schools. Teachers in urban schools reported being more likely to use dominating styles with their students' parents than with their peers. Based on these findings, the authors suggest continuing education for teachers to learn intentional ways of dealing with conflicts, both with peers and with students' parents. Jenkins, Ritblatt and McDonald (2008) measured 116 female preschool teacher's avoiding, cooperative and competitive conflict resolution styles using the Thomas-Kilman Conflict Mode Instrument in the US. Authors found out most educators (71 percent) favoured cooperative strategies over the other two, and competitive strategies were used less frequently by educators who had earned more units in child development.

There are few studies about teachers behaviour patterns in social conflict in Croatia. They have been previously researched as a competency in the context of the hidden curriculum. Earlier research carried out with students of preschool, and school education (Vlah \& Pinoza Kukurin, 2012) shows that the cooperation pattern is well-accepted by students. At first glance, this could be interpreted as a desirable stance; however, since avoidance, adjustment and winning are also well-accepted, authors assumed that acceptance of cooperation is only declarative (Vlah \& Pinoza Kukurin, 2012). Therefore, this study has shown that it cannot be said that students truly accept cooperation as a behaviour pattern in social conflict until they recognize the inadequacy of the patterns of avoidance, adjustment, winning and compromise for situations of social conflict. Thus, the authors are justified in broadening their arguments to encompass the thesis that teachers and educators should develop a cooperative attitude during their teacher training. Limits of previous research was an univariate scale that measured five social conflict behaviour patterns; thus, they recommend the usage of a measuring instrument with more measuring points when it comes to the further research of attitudes towards specific social conflict behaviour patterns.

The broader scientific purpose of this paper is to offer a contribution to the understanding of specific teacher's attitudes that theoretically could be a model for behaviour for their pupils. Thus, in the context of the theory of hidden curriculum, the applied purpose of the study is a better understanding of teacher's needs for further conflict resolution training.

The aim of this research is to identify primary teachers' attitudes towards social conflict behaviour patterns. According to recent studies, we assume that 
the teachers' attitudes towards behaviour patterns in social conflict are mainly cooperative.

\section{Methods}

\section{Sample}

The research sample comprised 155 teachers from 17 schools across the Primorje-Gorski Kotar County. The representation of teachers by the school was mostly evenly distributed; thus, a minimum of 4 and a maximum of 15 teachers from each school participated in the research. The average age of the teachers was 40 , and $96 \%$ of them were female. The average number of pupils in the classroom was 20 , with the teachers leading 38 groups of first-graders (25\%), 41 groups of second-graders (27\%), 36 groups of third-graders (23\%) and 28 groups of fourth-graders (18\%), while 12 teachers (7\%) taught mixed-grade after-school activities. On average, the majority of teachers had 15 to 19 years of work experience.

\section{Data collection instrument}

In order to measure attitudes towards the behavioural patterns in social conflicts, the Scale of Attitudes towards the behavioural patterns of adolescents in social conflicts was applied (Vlah, 2013; Tatalović Vorkapić et al., 2012). This scale had been constructed on a sample of adolescents (Vlah, 2013), and was applied to an adult sample for the first time in this study. It consists of a total of 22 data points grouped into three subscales: Cooperation $(\mathrm{N}=7)$, Avoidance / Adjustment $(\mathrm{N}=8)$ and Winning $(\mathrm{N}=7)$. Respondents marked the degree of agreement or disagreement with a particular statement on a Likert scale of four levels (1 - strongly disagree, 2 - mostly disagree, 3 - agree, 4 - completely agree). During the construction of the scale, a satisfactory level of reliability for the Cooperation subscale type Cronbach alpha: $(\alpha=0.84)$ was manifested. An example for a data point from each subscale is "Respect for the opinions of others in conflict situations is beneficial to everyone" for the Cooperation subscale, "It is best to skip awkward conversations and situations" Avoiding / Adjustment subscale ( $\alpha=0.74$ ) "It is important to strive to become and remain a winner" Winning subscale $(\alpha=0.83)$.

\section{Data collection and analysis}

The data were collected during the academic year of 2011/12 as a part of an inclusive research project that, apart from the attitudes towards behavioural patterns in conflict situations, dealt with the problems teachers experience in 
dealing with the emotional difficulties and behavioural problems of primary school pupils. Upon obtaining all the administrative permits, the interviewers delivered the two-sided questionnaires in sealed envelopes to schools. The teachers filled out the form voluntarily anonymously in about 15 minutes, after which they sealed the questionnaire in an envelope and returned it for data processing. The data on this paper were analysed with a component analysis and by determining the fundamental results based on the average values for each of the three subscales on linear data point composites.

\section{Results and discussion}

The component analysis was used on the obtained results so as to reduce the larger number of variables to a smaller number of theoretically interpretable factors. The component analysis of the main components extracted six components with characteristic roots greater than 1, which carried $66.19 \%$ of the variance of the scale results. Given that the factors were not logically interpretable, the need existed to verify the simpler structure. The results of the Cattel's scree test implemented also indicated this, while suggesting a triple factorial structure up to the uniform decline of the characteristic roots after the third factor. With the aim of identifying theoretically interpretable factors without overlapping the same data points in different factors, we decided to examine the structure of the expected three components, upon which we then conducted an oblique oblimin rotation. The typical root for all of the three factors retained was greater than $1(4.758 ; 3.298 ; 2.447)$, and the factors explained $50.014 \%$ of the variance results of the retained data points. Significant correlations between factors were found $(\mathrm{r} 1-2=-0.121 ; \mathrm{r} 1-3=0.219 ; \mathrm{r} 2-3=-0.169)$. The statement that reads, "When someone makes me angry with their actions or words, then they deserve to be beaten" had a communality lower than 0.3 (.068) and was omitted from the further processing for determining the fundamental results. All other statement had sufficient communalities ranging from .303, the lowest, to .697 , the highest. All statements in the matrix form had a saturation greater than .30 and there were no concurrent saturations on multiple factors in any of the observed statements.

As in previous studies (Vlah, 2013; Vlah et al., 2011), a triple factorial structure of a set of 22 statements was obtained. 
Table 1. The first factor of the matrix form in the factor analysis of the Scale of Attitudes towards social conflict - Avoidance/Adaptation

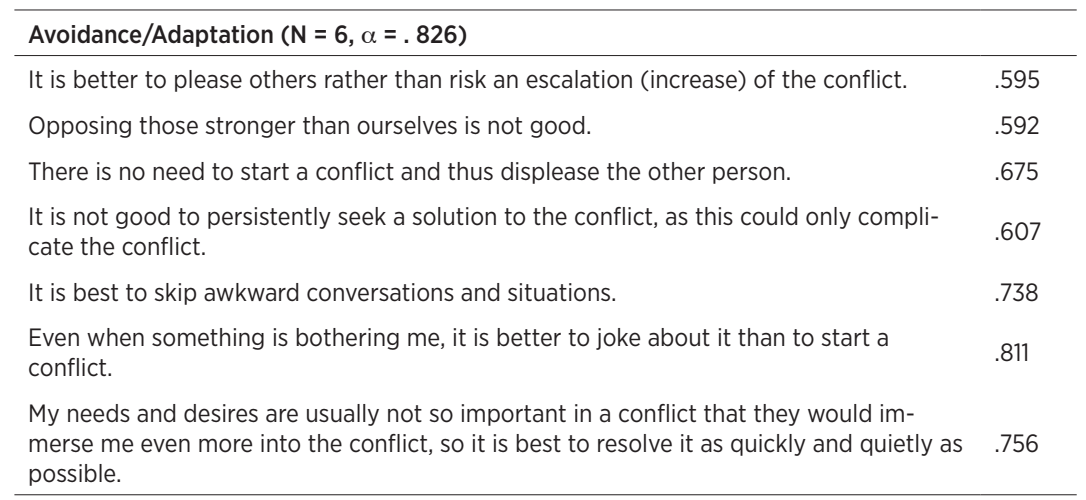

The first factor, which is shown in Table 1, consists of the subscale statements of Avoidance/Adaptation and describes the pattern of Avoidance/Adaptation in social conflict with a teacher. It carries $22.656 \%$ of the variance. This is a pattern that is characterized by non-intervention in the conflict and an insufficient satisfaction of one's own needs and the needs of others in the conflict. It appears mostly out of fear of resentment or injuring the other parties involved in the conflict and is, in theory, considered undesirable because it does not give an opportunity to the involve parties to solve their unexpressed problems in the long run. Instead, the discontent caused by the failure to resolve the problems piles up and threatens to escalate through unconstructive behaviour such as violence or bullying.

Table 2. The second factor of the matrix form in the factor analysis of the Scale of Attitudes towards social conflict - Cooperation

\begin{tabular}{lc}
\hline Cooperation $(\mathrm{N}=7, \alpha=.838)$ \\
\hline It is always good to look for different ways to solve problems in the conflict. \\
One should search for a solution that is truly acceptable and useful to everyone. \\
A solution should be found that is truly acceptable and useful to everyone. \\
In order to find the right solution to the conflict, it is always good to honestly discuss \\
everything. \\
In the long run, it pays off to share ideas regarding the resolution of the conflict with \\
your opponent, even when you are angry with him / her. \\
Acknowledging the opinion of the opponent in the conflict is beneficial to everyone. \\
It is very important to respect the goals, values and desires of all parties in the conflict. & .640 \\
\hline
\end{tabular}


The second factor (Table 2) carries $15.71 \%$ of the variance and it describes well the attitude toward reciprocity and mutually acceptable ways of meeting the needs of both the parties involved in the conflict: cooperation. This is a pattern that demands investing the most time, as well as the energy and willingness to respect the other parties in a conflict, together with a willingness to accept pluralism as a possible outcome of the conflict. This pattern requires a high amount of socioemotional maturity and knowledge about social skills in a conflict.

Table 3. The second factor of the matrix form in the factor analysis of the Scale of Attitudes towards social conflict - Winning

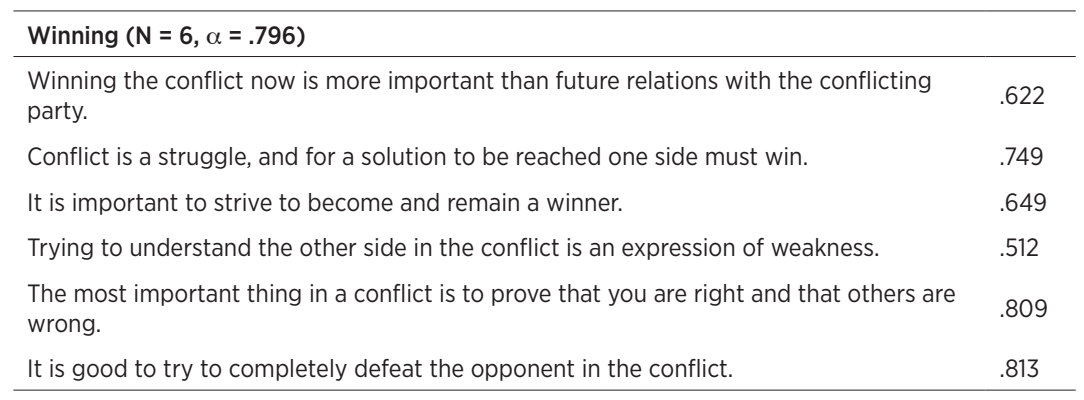

The third factor in the structure of this scale was formed from data points describing the imposition of one's personal dominance until the opponent finally realizes his/her own subjugation. In this pattern, which carries $11.651 \%$ of the variance, the tendencies toward exclusion and undemocratic behaviour in social conflicts were manifested because this pattern does not allow the possibility of multiple solutions in which the other party could take pleasure, as well. This form knows no compassion for the perceived opponent in the conflict.

As is evident from Tables 1, 2 and 3, satisfactory measures of Cronbach alpha reliability were obtained using the Scale of Attitudes towards social conflict in this sample of respondents: for the subscale Cooperation $(\alpha=.838)$, for the subscale Avoidance/Adjustment $(\alpha=.826)$ for the subscale Winning $(\alpha=.796)$.

Table 4. Descriptive analysis of the average values and Spearmen correlations between the behavioural patterns in social conflicts

\begin{tabular}{lcccccc}
\hline & M & SD & Min & Max & Avoidance/Adaptation & Cooperation \\
\hline Avoidance / Adaptation & 2.296 & .555 & 1.00 & 4.00 & - & \\
Cooperation & 3.670 & .555 & 2.43 & 4.00 & -.130 & - \\
Winning & 1.405 & .448 & 1.00 & 4.00 & $.191^{*}$ & $-.262^{* *}$ \\
\hline
\end{tabular}

Note: $M=$ the arithmetic mean of all the results, $S D=$ deviation from the arithmetic mean of all results; Low $=$ lowest result value, Max $=$ maximum result value, ${ }^{*}(p<0.05),{ }^{* *}(p<0.01)$ 
According to the results in Table 4, the respondents consider Cooperation to be the most acceptable, and Winning the least acceptable behavioural pattern in social conflicts. Deviations from these average positions are very small. It is evident that the minimum value in the pattern of Cooperation indicates that there is not a single answer that fully rejects the pattern of Cooperation. Given the implications of this attitude on the hidden curriculum in schools, i.e. its interpretation from the professional angle of the teaching profession, this is a highly desirable result (Lave \& Wenger, 1991, according to Miljak, 2007; Cornile et al., 1999; Altras Penda, 2005). A teacher who highly values Cooperation probably displays more cooperative behaviour. Cooperation demonstrates a low level of negative correlation with Winning, which means that accepting Cooperation indicates rejection of Winning and vice versa. This result confirms the principles of the conflict resolution theory (Wilmot \& Hocker, 1998; Weeks, 2000). Thus, we can infer that it is unlikely that a teacher who is behaving cooperatively will also strive to defeat his/her opponent in the conflict.

According to the results from Table 4, Winning has a very weak positive correlation with Avoidance/Adaptation, which indicates that the acceptance of Winning means the acceptance of Avoidance/Adaptation and vice versa. This result also confirms the conflict resolution theory, according to which Winning and Avoidance/ Adaptation are not very useful for building constructive relations in the future and achieving a good connection (Weeks, 2000). A teacher who approves of Winning as a strategy at the same time also avoids conflicts instead of resolving them constructively. This pattern combination is considered undesirable for teachers, in light of the messages that such behaviour can send to the pupils as part of the hidden curriculum (Rose \& Doveston, 2008). These two theoretically undesirable behavioural patterns are less accepted in social conflicts among teachers than cooperation is.

Teachers who accept Avoidance/Adaptation and Winning should be involved in programmes that focus on developing social skills and transformation attitudes toward social conflicts, which is a practice that is common around the world (Tschannen-Moran, 2001; Welch, 1998). A total of 94 primary school teachers (60\%) mostly agreed with statements affirming Avoidance/ Adaptation, while ten (1.5\%) teachers completely agreed with the Avoidance/ Adaptation patter in social conflicts. After examining the responses for the pattern of Winning, it is observable that eight (5\%) teachers generally agreed with statements affirming Winning, while one teacher completely agreed with them.

For the teachers who simultaneously expressed acceptance of Cooperation, Avoidance/Adaptation and Winning, it can be said that their acceptance of Cooperation is actually declarative, as was also ascertained in the study of Vlah and Pinoza-Kukurin (2012). 
This study views attitudes towards social conflicts as one of the elements of everyday pedagogical practice (i.e. of the hidden curriculum) and suggests first improving the practice of primary education, and then the relevant theory. An indispensable guideline contained within this interpretation implies that what younger generations learn from the older ones, from their peers, and from their immediate environment in the context of observational learning theory is precisely which attitude patterns regarding social conflicts are acceptable.

This indicates the importance of focusing on the improvement of one's views on social conflicts, as they also influence that "something else", which pupils and young people largely adopt through education: the hidden curriculum (Seddon, 1983; Cindric et al., 2010; Miljak, 2007). It is possible to rethink the acceptable attitudes regarding social conflicts and improve them through the integration of professional content into teacher training programmes, which would improve future educators' competencies, knowledge and skills about the invisible, yet important patterns that pupils learn from their teachers. In addition to contemplating this issue within the context of teacher training, learning opportunities can also be made within the framework of lifelong learning for experienced teachers to reflect upon the elements of the hidden curriculum and how to utilize them to achieve maximum educational benefits, as such teachers are able to identify the importance of these elements in their everyday lives: in the growth and development of classes of pupils in their formative years, for whom the teacher is a model for learning (Čepić et al., 2015). Furthermore, we find it important to stress that, when it comes to learning from a model, not every teacher represents an equally efficient model to pupils. Pupils tend to imitate the model they find more competent, regardless of any perceived similarities to the one seen as incompetent. Furthermore, model efficiency also depends on the personality of the observer, e.g. easily frightened and anxious pupils more frequently imitate a model that displays fear than confident and self-assured pupils do (Vizek Vidović et al., 2003). This is one of the methodological issues that should be analysed in future studies. In addition, we suggest that future studies examine the causal relationship between teacher's behaviour in social conflicts and the behaviour of his/her pupils in order to obtain clear data on this issue.

When speaking of hidden curriculum, we are referring to a completely different curriculum: everything that is considered self-explanatory and is uncritically accepted in a pedagogical situation. Learning about the hidden curriculum raises questions on the very essence of knowing, learning and teaching. Discovering covert institutional meanings marks the end of the view of educators' and the teachers' positions as neutral and reveals the broader social influence of pre-schools and schools, educators and teachers who either participate 
in the reproduction of social inequality or work to oppose it (Feldman, 1992 as cited in Dolar Bahovec \& Bregar Golobič, 2004). Thus, we believe that lessons on conflict management during teacher training, as well during lifelong learning, are a very important part of the professional development of competent and modern teacher, which is also confirmed by previous the studies (Tschannen-Moran, 2001; Welch, 1998; Jenkins et al., 2008). Especially if contemporary education strives towards achieving a democratic environment and a respect for diversity. It is important to become aware of one's own values, attitudes and manifested behaviours that we utilize in solving different problems and in various everyday social situations (Čepić \& Tatalović Vorkapić, 2015). These values are internalized and become part of one's personality through the experience of family life (upbringing), school (education, upbringing, socialization in peer groups) and the wider community (socializing into the norms of the sociocultural environment).

\section{Conclusions}

As a result of the stated research aim, it has been ascertained that, out of the three behaviour patterns in social conflict offered, teachers in the PrimorjeGorski Kotar County of Croatia accept the pattern of Cooperation the most, while accepting the conflict behaviour pattern of Winning the least. Winning is correlated negatively with Cooperation and positively with Avoidance/Adaptation. Given that theory presumes that the behaviour of teachers is an important influence on the hidden curriculum in classrooms, we hope that the contribution of this study will be to encourage further research.

We have discovered that a number of employed teachers exist who simultaneously accept both of the non-constructive behaviour patterns in social conflict: Winning and Avoidance/Adjustment. According to Conflict Management Theory, these teachers need further education about cooperative behaviour in conflict situations, so they should be involved in lifelong learning programmes that focus on building social skills in situations of conflict.

\section{References}

Penda, I. (2005). The Fundamental Values of the European Union - From Utopia to Reality. Politička misao, 18(3) 157-172.

Bandura, A. (1978). The Self System in Reciprocal Determinism. American Psychologist, 33, 344-358. Bandura, A. (1986). Social Foundation of Thought and Action: A social cognitive theory. Englewood Cliffs, NJ: Prentice-Hall. 
Basit, A., Rahman, F., Jumani, N., ul Hasan C., S., \& Malik, S. (2010). An analysis of conflict resolution strategies in Pakistani schools. International Journal of Academic Research, 6(2), 212-218. Bašić, S. (2000). The Concept of the Hidden Curriculum. Napredak, 141(2), 170-181. Bloom, B. S. (1972). Innocence in Education. The School Review, 8o(3), 333-352.

Cindrić, M., Miljković, D., \& Strugar, V. (2010). Didactic and Curriculum. Zagreb: IEP-D2.

Cornille, Th. A., Pestle, R. E., \& Vanwy, R. W. (1999). Teachers' conflict management styles with peers and students' parents. International Journal of Conflict Management, 10(1), 69-79.

Čepić, R., Tatalović Vorkapić, S., Lončarić, D., Anđić, D., \& Skočić Mihić, S. (2015). Considering Transversal Competences, Personality and Reputation in the Context of the Teachers' Professional Development. International Education Studies, 8(2), 8-20. doi:10.5539/ies. v8n2p8 Čepić, R., \& Tatalović Vorkapić, S. (2015). Teachers' Informal Learning and Personality: Context and Challenges in Professional Practice. In T. Grušovnik (Ed.), Obzorja učenja: vzgojno-izobraževalne perspective (pp. 283-298). Koper: Univerza na Primorskem, Znanstveno-raziskovalno središče, Univerzitetna založba Annales Ludus.

Dolar Bahovec, E., \& Bregar Golobič, K. (2004). The School and Kindergarten Through mirror. Manual for Kindergartens, Schools and Parents. Ljubljana: DZS.

Fields, B. (1998). Interpersonal Conflict in Schools: How teachers manage conflict in the workplace.

Education and Society, 16(1), 55-72.

Frymier, A. B., \& Houser, M. L. (2000). The Teacher-Student Relationship as an Interpersonal Relationship. Communication Education, 49(3), 207-219.

Galtung, J. (2000). Conflict Transformation by Peaceful Means (the Transcend Method). New York: United Nations Disaster Management Program.

Gordon, D. (1982). The Concept of the Hidden Curriculum. Journal of Philosophy of Education, 16(2), $187-198$.

Hodkinson, P. (2005). Learning as Cultural and Relational: Moving Past Some Troubling Dualisms. Cambridge Journal of Education, 35(1), 107-119.

Jančec, L., Tatalović Vorkapić, S., \& Lepičnik Vodopivec, J. (2014). Hidden curriculum determinants in (pre)school institutions - implicit cognition in action. Book Chapter to be Appeared. In J. Zheng (Ed.), Exploring Implicit Cognition: Learning, Memory, and Social Cognitive Processes (pp. 216-242). IGI-Global.

Jenkins, S., Ritblatt, S., \& MCDonald, J. S. (2008). Conflict resolution among early childhood educators. Conflict Resolution Quarterly, 25(4), 429-450.

McDiarmid, G. (1987). The Development of a Conceptual-Empirical Theory of Curriculum. Interchange, $18(3), 38-62$.

Miljak, A. (2007). Learning by Doing and Participating in a Group of Professional Educators. In V. Previšić, N. N. Šoljan, \& N. Hrvatić (Eds.), Pedagogy: Towards lifelong education and the knowledge $\operatorname{society}_{1}$ (pp. 201-214). Zagreb: Croatian Pedagogic Society.

Morris-Rothspupil, B. K., \& Brassard, M. R. (2006). Teachers' Conflict Management Styles: The Role of Attachment Styles and Classroom Management Efficacy. Journal of School Psychology, 44(2), 
$105-121$.

Pennington, D. C. (2008). Fundamentals of Social Psychology. Zagreb: Naklada Slap.

Rose, R., \& Doveston, M. (2008). Pupils Talking about Their Learning Mentors: What Can We

Learn?. Educational Studies, 34(2), 145-155.

Seddon, T. (1983). The Hidden Curriculum: An Overview. Curriculum perspectives, 3, 1-6

Tatalović Vorkapić, S., Vlah, N., \& Mejovšek, M. (2012). Construction of the Scale of Attitudes

Towards Behaviour Patterns in Social Conflicts. Suvremena psihologija, 15(2), 144-155.

Thomas, K. W., \& Kilmann, R. H. (1977). Developing a Forced-Choice Measure of Conflict-Handling

Behavior: The "Mode"Instrument. Educ. \& psychol. Measurement, 1(1), 309-25.

Tschannen-Moran, M. (2001). The Effects of a State-Wide Conflict Management Initiative in Schools.

American Secondary Education, 29(3), 2-32.

Verhoeve, S. (2008). Peace-Teaching: Evaluating the Role of Education in Post-Conflict Cambodia.

Undercurrent, 5(3), 45-52.

Vizek Vidović, V., Rijavec, M., Vlahović-Štetić, V., \& Miljković, D. (2003). Psihologija Obrazovanja. Zagreb: IEP-VERN.

Vlah, N. (2010). Concept and structure of social conflict. Educational Sciences, 2(12), 373-385.

Vlah, N. (2013). Desirable behavior of young people in conflicts. Zagreb: Biakova d.o.o.

Vlah, N., Vejo, E., Bijedić, M., \& Muftić, E. (2011). The Relationship Between Attitudes on Behaviour Patterns in Social Conflicts and the Levels of Behavioural Disorders in Adolescents. Defectology, $17(1), 30-34$.

Vlah, N., \& Pinoza Kukurin, Z. (2012). Attitudes of the Students of the Faculty of Teacher Education in Rijeka towards Models of Behaviour in Social Conflicts. Napredak, 153(1), 39-52.

Weeks, D. (2000). The Eight Essential steps to Conflict Resolution. Osijek: Sunce.

Welch, M. (1998). Collaboration: Staying on the Bandwagon. Journal of Teacher Education, 49(1), 26-37.

Weldon, G. (2010). Post-conflict Teacher Development: Facing the Past in South Africa. Journal of Moral Education, 39(3), 353-364.

Wilmot, W. W., \& Hocker, J. L. (1998). Interpersonal Conflict. USA: McGraw-Hill. Zembylas, M. (2011). Peace and Human Rights Education: Dilemmas of Compatibility and Prospects for Moving Forward. Prospects: Quarterly Review of Comparative Education, 41(4), 567-579. 


\section{Biographical note}

Nataša Vlah is Assistant Professor in Behavioral Disorders, a branch of the scientific field of Special Education. She teaches at the Faculty of Teacher Education and the Faculty of Humanities and Social Sciences at the University of Rijeka. Since 1997 she has been developing her professional interests in the prevention of behavioral problems in children and adolescents, both in practise and through academic achievements. She has 14 years of experience as a social educator in schools and correctional and preschool institutions. She has led several research projects, which have resulted in her publishing more than 15 scientific papers.

LuCIJA JANČEc, Ph.D. Student, works in Dormitory 'Podmurvice' in Rijeka, and as an external associate in NGO called 'Naša djeca' (english: Our children) in Opatija. Her general interests are working with children and their parents, but also research of the hidden curriculum in education, its interrelatedness with other fields of research through interdisciplinary studies. Her study of the hidden curriculum is an important feature in the raising of awareness of microelements in pedagogical work in institutions as well as out of institutional life. She has been actively involved within various interdisciplinary parents and experts groups.

RENATA ČEPIĆ, Ph.D. is assistant professor and currently teaches students at Faculty of Teacher Education, University of Rijeka, Croatia. Her academic and scientific interests are focused on the lifelong education/learning, continuing professional education and development of educators, learning organizations, education of adults, as well as research in education and modern trends and innovation in education. She has published numerous pedagogy and andragogy related scientific papers and she has been actively engaged in several research projects in the field of education. 